\title{
Kernos
}

Revue internationale et pluridisciplinaire de religion grecque antique

$32 \mid 2019$

Varia

\section{Naming the Gods of Others in the Septuagint: Lexical Analysis and Historical-Religious Implications}

\section{Anna Angelini}

\section{(2) OpenEdition}

\section{Electronic version}

URL: https://journals.openedition.org/kernos/3150

DOI: $10.4000 /$ kernos.3150

ISSN: 2034-7871

\section{Publisher}

Centre international d'étude de la religion grecque antique

\section{Printed version}

Date of publication: 1 December 2019

ISBN: 978-2-87562-229-7

ISSN: 0776-3824

\section{Electronic reference}

Anna Angelini, "Naming the Gods of Others in the Septuagint: Lexical Analysis and Historical-Religious Implications", Kernos [Online], 32 | 2019, Online since 01 October 2021, connection on 01 February 2022. URL: http://journals.openedition.org/kernos/3150 ; DOI: https://doi.org/10.4000/kernos.3150

This text was automatically generated on 1 February 2022.

Kernos 


\title{
Naming the Gods of Others in the Septuagint: Lexical Analysis and Historical-Religious Implications
}

\author{
Anna Angelini
}

This paper was presented in May 2018 at the Oxford Seminar in Advanced Jewish Studies "Greek Expanded, Greek Transformed: the Septuagint and the Cultural World of the Translators". It is my pleasure to thank the conveners and all the participants in the seminar for their stimulating questions and the fruitful discussions. Special thanks are also due to Doralice Fabiano, Christophe Nihan and Scott Scullion for their useful remarks, to the anonymous readers for their suggestions, and to Julia Rhyder for her careful revision of my English.

\section{Introduction}

1 At a first sight, the Septuagint (LXX) does not seem to be particularly innovative in the way it refers to foreign gods, to the gods of the nations, or to any recipient of cults which Israelites must avoid. In most cases these gods are simply referred to in a way which we could define as "denotative": they are called $\theta \varepsilon o$, i.e., without differentiation from the name of the god of Israelites, as both El and Yhwh can be rendered with $\theta \varepsilon$ ć ${ }^{1}$ However, in several instances translators adopted a specific "connotative" vocabulary. I

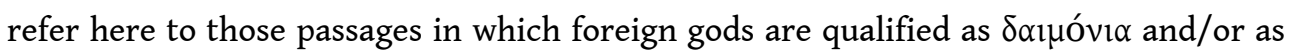
$\varepsilon$ हi $\delta \omega \lambda \alpha$. These qualifications deserve further exploration, as here it turns out that the LXX plays a crucial role in the semantic evolution of both the notions, of "demon" and "idol" respectively. In what follows, I will focus on some linguistic and cultural aspects which are methodologically relevant to appreciate the activity of the translators, on the one hand, and to understand the fashioning of the category of demon during Hellenistic times, on the other. Such aspects are the relationship of the LXX with its Vorlage or the extant Hebrew text (henceforward abbreviated as $\mathrm{MT}^{2}$ ), and the possible innovation brought by the LXX both on lexical and conceptual level; the interactions

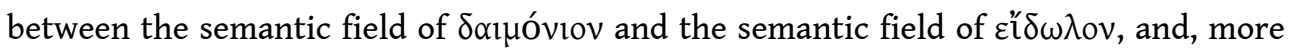


generally, the way in which the discourse on foreign cults can be (or not be) intertwined with a discourse on divine images; the possible patterns which can be detected in the use of these two categories within the LXX; the role of LXX witnesses vis-à-vis the larger Hellenistic religious and cultural context (Greco-Roman religion and philosophy on the one hand, Hellenistic Judaism and Second Temple literature on

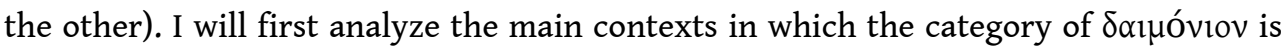

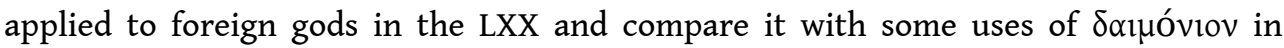
classical and post-classical literature. I will then consider the relationship between

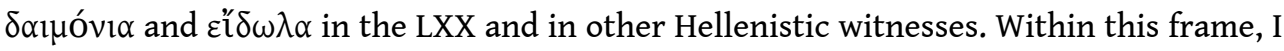
will specifically focus on the semantic value of $\varepsilon$ k $\delta \omega \lambda \alpha$ in two Pentateuchal passages which are relevant for my discussion, namely Exodus 20:4 and Deuteronomy 32:21, and I will suggest a new interpretation for the meaning of $\varepsilon$ í $\delta \omega \lambda \alpha$ in the decalogue, against the background of papyrological evidence. I will conclude by highlighting some wider implications of the present study.

\section{The gods of the others as $\triangle$ AIM'ONIA in the LXX}

Even a quick survey of the distribution of the word Saluóviov in the LXX makes clear that its main context is to be sought in the polemics against foreign gods, although the word is also used elsewhere in the LXX.3 The only Pentateuchal occurrence of the word

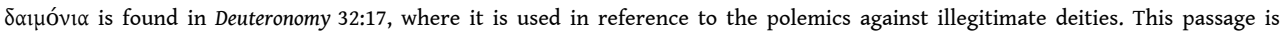
reproduced without variation in Odes 2:17. Two related passages, in which dependence on Deut 32 produced a very similar text are Psalms 105:37 (= 106:37 MT) and Baruch 4:7. In this context one should also include Psalms 95:5 (= 96:5 MT), as well as two out of the four occurrences of the word that are found in Isaiah, namely Isaiah 65:3 and 11. The Hebrew referent is šedîm in Deut 32 and Ps 105; the same word could have probably been found in a Hebrew Vorlage of Bar 4 (if this Vorlage ever existed).4 In Ps 95:5 the referent is 'elîlim, a term to which I will return later. The two occurrences in Isaiah are somewhat different: Isa 65:3 is an expansion with no equivalent in the extant Hebrew text. In Isa 65:11 the equivalent is Gad, usually translated by "Fate" or "Fortune", a deity which was very popular in the Hellenistic and Roman Near East.5 Deut 32:17 therefore emerges as the most influential passage, and thus as warranting a closer analysis. This text belongs to the so-called "Song of Moses", which summarizes the history of Israel going back to its mythical origins. Typically of Israel's history, the Israelites repay Yhwh's blessings and gifts with infidelity. Their disloyalty is demonstrated, among

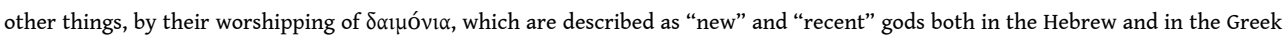
text:6

\begin{tabular}{|l|l|}
\hline 16 & They made me jealous with strange cults, \\
\hline & with abominations they provoked me ( $k$ 's) \\
\hline 17 & They sacrificed to demons (šedîm), which are not God (lo' 'Eloah), \\
\hline & deities which they did not know, new, \\
\hline & the ones recently arrived, which their fathers did not fear. \\
\hline
\end{tabular}

Deut 32:16-17 (LXX):

\begin{tabular}{|c|c|}
\hline$\theta$ & 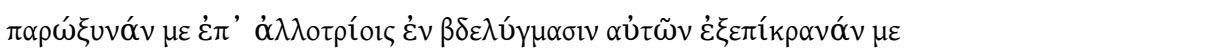 \\
\hline & 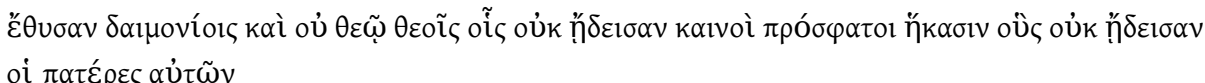 \\
\hline
\end{tabular}




\begin{tabular}{|l|l|}
\hline 16 & They provoked me with foreign cults, \\
\hline & in their abominations they embittered me \\
\hline 17 & they sacrificed to demons and not to God, \\
\hline & to gods which they did not know. \\
\hline & New, recent ones have arrived, \\
\hline & which their fathers did not know. \\
\hline
\end{tabular}

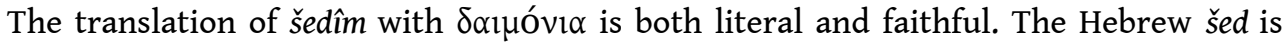
usually considered as a loanword from the akkadian šedu, ${ }^{7}$ which can be either a protective spirit or a malevolent demon, especially when it is followed by the qualification "evil" (lemnu-HUG). ${ }^{8}$ Šed is attested in Qumran about 15 times, in the forms šdym and šd'ym, both in the Hebrew and in the Aramaic texts where it means "demon". 9 It appears quite frequently in Jewish Aramaic and Syriac, in the forms šyd, šyd', šydh and šydt', especially in the lists of demons and evil spirits found on amulets and incantation bowls of late antiquity. ${ }^{10}$ It is attested in the Targums, ${ }^{11}$ and eventually serves as the generic name for "demon" in rabbinic and modern Hebrew. ${ }^{12}$ The same meaning applies well to the context of Deut 32. From the perspective of a modern reader, then,

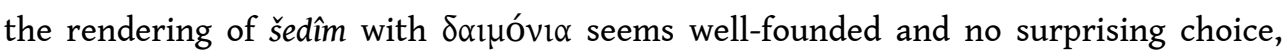
since we are used to deriving the modern idea of "demon" from the Greek $\delta \alpha i ́ \mu \omega v$. From an ancient perspective, though, things are much more complex, as the Greek notion of $\delta \alpha i ́ \omega \nu$ is much broader and more articulated than that of "demon". The category of $\delta \alpha i ́ \mu \omega v$ has a wide semantic range, which varies from being a synonym for "god" ( $\theta \varepsilon o ́ \varsigma)$, to "soul", "spirit of the dead", "destiny", et cetera. ${ }^{13}$ While the $\delta \alpha i ́ \mu \omega \nu$ has almost no mythical background, it is a highly-operational concept in the context of Greek philosophy, from pre-Socratic times to late antiquity. The polysemic nature of this notion remains well attested during Hellenistic times. However, Giulia Sfameni Gasparro has pointed out in a number of studies how the notion of $\delta \alpha i ́ \mu \omega v$ as a somehow "intermediate being", occupying a specific intermediate space within the cosmos, clearly distinguished from the gods and closer to the category of heroes, is a product of late classic and Hellenistic philosophy. ${ }^{14}$ Such a characterization is largely developed not only in the Platonic dialogues, where $\delta \alpha i ́ \omega \omega v$ is the mediator par excellence between humans and gods, but also among Pythagoreans. Pythagorean philosophical traditions are more difficult to date, as the history of their textual transmission is particularly complex. Although they are usually considered very ancient, the majority of our written witnesses do not predate the Hellenistic period. They seem therefore to draw upon previous beliefs and philosophical notions, which can evince significant differences. One interesting document is the so-called Pythagorean Commentaries or Memories, known from Alexander Polyhistor, via Diogenes Laertius: ${ }^{15}$

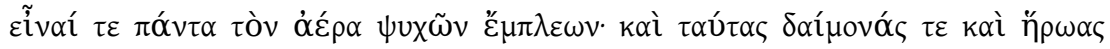

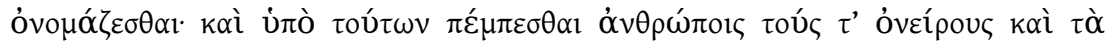

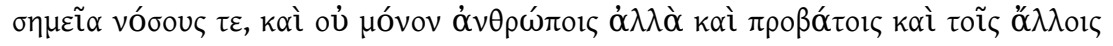

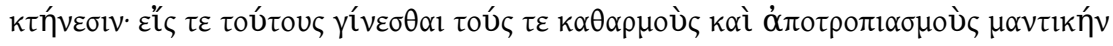

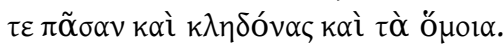

The whole air is full of souls. We call them daimones and heroes, and it is they who send dreams, signs and illnesses to men - and not only to men, but also to sheep 
and other domestic animals. It is toward these daimones that we direct purifications and apotropaic rituals, all kinds of divination, kledonomancy and other things of a similar kind.

It should be clear that such traditions do not arise suddenly in Hellenistic times. A

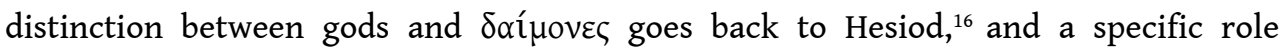
attributed to $\delta \alpha$ í times in Dodona. ${ }^{17}$ However, during the Hellenistic period the number and the typology

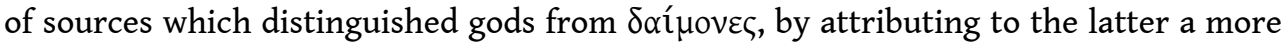
specific field of action, increases considerably. In the passage from Polyhistor, two

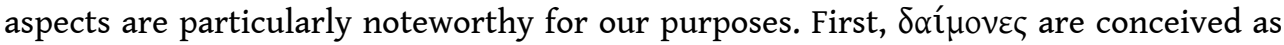
intangible and incorporeal beings, as they are explicitly defined $\psi v x \alpha$ wi which "fill the air". ${ }^{18}$ The specific rituals addressed to them are also interesting in that they differ from ordinary sacrificial practice: they are apotropaic rituals, oracular practices and divination (dreams), as well as purification rituals. Both these aspects show some connection with the ideas expressed in Deut 32, on which I will return later.

If we now go back to the Greek text of Deut 32:16, one element which requires an

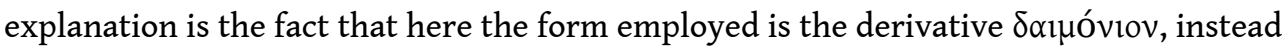

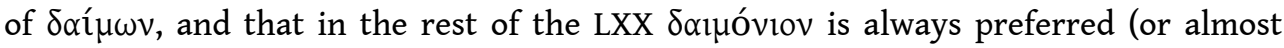
always), over $\delta \alpha i ́ \omega \omega .{ }^{19}$ While as an adjective the word goes back to Homeric times, its use as a neutral substantive is relatively recent, finding its earliest occurrences in

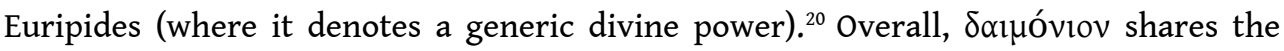
semantic ambiguity of $\delta \alpha i \mu \omega v$, although the contexts in which the former is used are fewer and less differentiated than those of the latter. One of the most explicit witnesses which attests to the ambiguity of Saluóviov is the famous passage of the Apology of

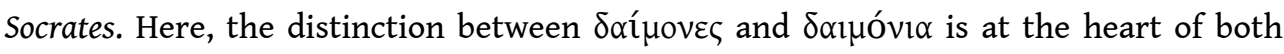
Socrates' accusation and Socrates' defense. The charge against Socrates brought by

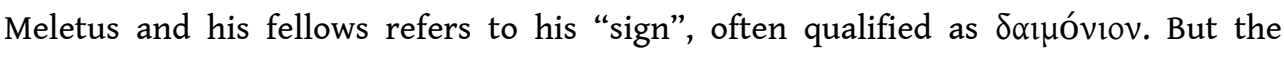

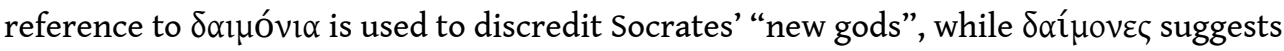
the substantial identification between these entities and $\theta \varepsilon o$. The new deities are

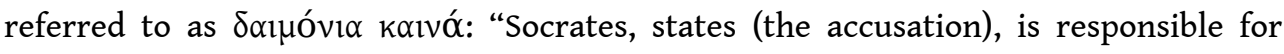
corrupting the youth and for not acknowledging the gods ( $\theta \varepsilon \circ$ ćc) the state

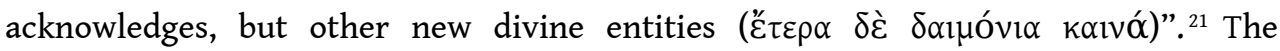
similarity between this expression and the LXX of Deut 32, where the new gods are also qualified as kaıvoí, has been occasionally noted. Indeed, it might appear quite striking at first sight. However, these similarities should not be overstated. The expression

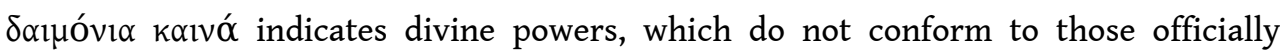
worshipped by the city; they are, therefore, illegitimate. On the contrary, Socrates'

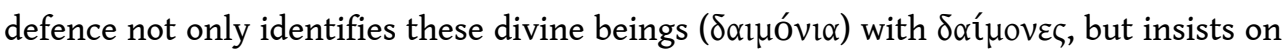

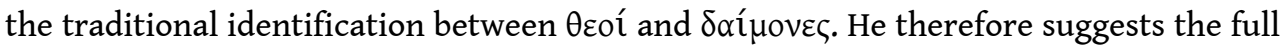
divinity of $\delta \alpha^{\prime} \mu \operatorname{lov}_{\varepsilon}$, and by consequence the internal contradiction of Meletos' charge:

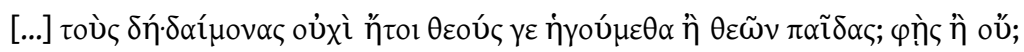

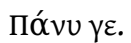

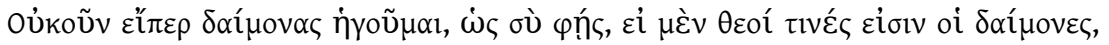

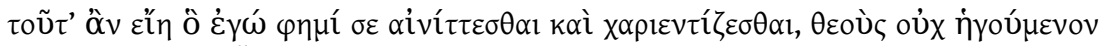

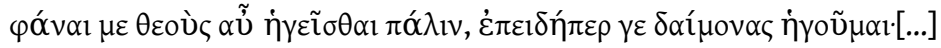

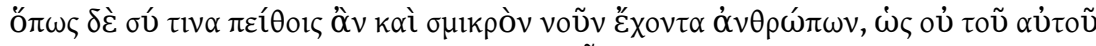

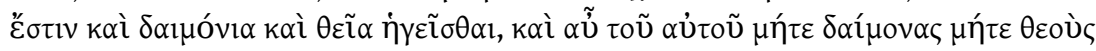

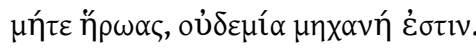


"But do we not think that daimones are gods or children of gods? Yes or no?" "Certainly yes."

"Then, since I do believe in daimones, as you say, if the daimones are a kind of gods, this is what I mean when I say that you speak in riddles and in jokes, as you say that I do not believe in gods and then again that I do, since I believe in daimones. [...] In no way could you persuade anyone, even of small intelligence, that is possible for the same man to believe both in demons and gods, and on the other hand for the same man not to believe nor in daimones, nor in gods, nor in heroes."

Despite the similarities in the expressions used by Plato and by the Greek translator of Deuteronomy, these passages belong to very different contexts and have very different conceptual backgrounds. In Plato there is no equivalent to the issue of "false gods" that is found in the biblical text. In the Apology the status of these entities is questioned only insofar they have not been officially integrated into the public cult, and therefore represent a danger to the city's interests. ${ }^{22}$ In other words, in the Athenian context there is no "theological" conflict at stake, but mainly a procedural and practical issue. Therefore, these parallels do not necessarily reveal an influence of Platonic language or of Platonic theories on the work of the translator. ${ }^{23}$ Instead, they attest only to the facts that, first, qualifying a cult or a god as "new" is a widespread and rather common strategy of delegitimization in antiquity; second, that the word $\delta \alpha \mu$ óvı $\alpha$ can be used, to a certain extent, in opposition to $\theta \varepsilon o$ í and to $\delta \alpha i ́ \mu o v \varepsilon \varsigma$ itself, with deprecatory force.

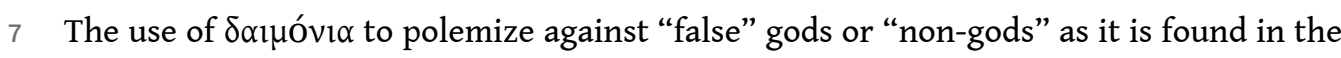
LXX of Deuteronomy 32 appears, in itself, as rather new and specific. However, a series of

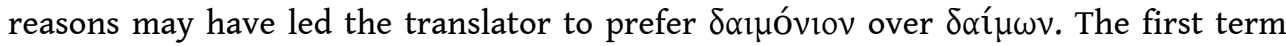
has fewer connotations from the perspective of Greek religion and philosophy. Its semantic spectrum is not only more reduced, but also somehow distinctive: unlike $\delta \alpha i ́ \mu \omega v, \delta \alpha \iota \mu o ́ v ı v$ is not a normal general term for "god" and is not frequently used as a synonym for $\theta \varepsilon$ có. At the same time, the word keeps a certain degree of ambiguity and lacks specification in defining divine power. These features prove useful to the translator of Deuteronomy but also to later translators, who adopt a more "free" style, as can be seen for example in the case of the translator of Isaiah. ${ }^{24}$

The idea of demons as recipients of improper rituals will find further development in later texts, as for example Ps 105:37. Here, verses 35-39 are inserted in a context

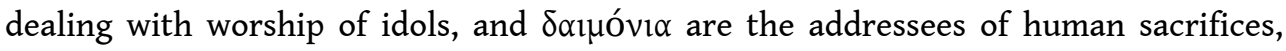
described with an emphasis on the blood that is shed:

Ps 105:36-38 (= 106:36-38 MT)

\begin{tabular}{|c|c|}
\hline 36 & 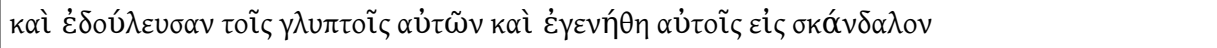 \\
\hline 37 & 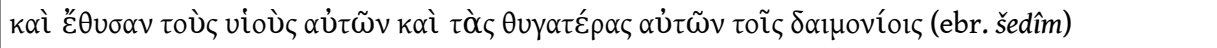 \\
\hline 38 & 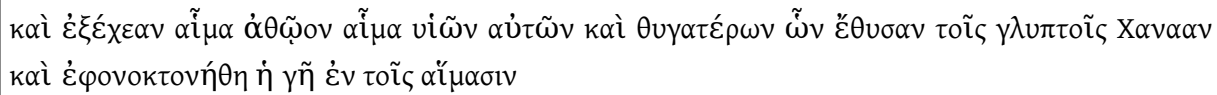 \\
\hline
\end{tabular}

36 And they served their idols (lit. carved images) and it became a trap for them,

37 they sacrificed their sons and their daughters to the demons,

38 and they poured out innocent blood, the blood of their sons and daughters whom they

sacrificed to the idols of Canaan, and the land was defiled with the blood 
This mention has no equivalent in the Hebrew text, which reads:

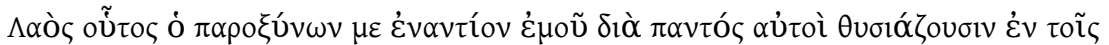

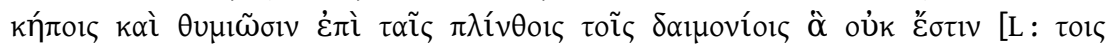

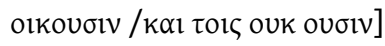
the gardens and burn incense on the bricks to the demons, which do not exist

Mention of $\delta \propto \iota \mu o ́ v ı \alpha$ in a list of forbidden cults is also found in the LXX of Isa 65:3:

This people who provoke me, in front of me, continuously: they offer sacrifices in

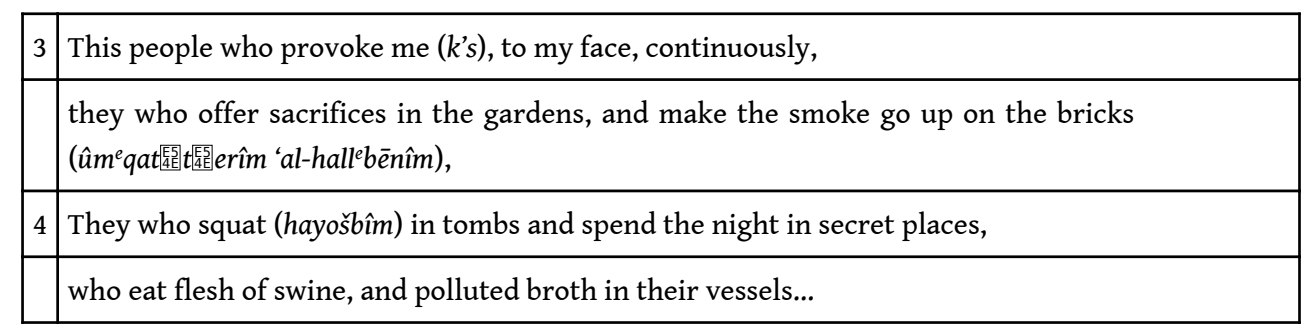

11 The Hebrew and the Greek expressions used to describe the offense towards Yhwh are similar to those employed in Deut 32 (see for example the verb k's/ $\pi \alpha \rho \circ \xi u v \omega$ ), and are quite typical of Deuteronomic language. ${ }^{25}$ The practices described in the Hebrew text of v. 3-4 are not easy to identify precisely. However, the "sacrifices in gardens" could indicate a cult to Asherah, as the association between gardens and the sacred tree which is usually considered to represent the goddess appears in Isa 1:29. ${ }^{26}$ Alternatively, it could refer to the god of vegetation Adonis-Tammuz, whose cult was already popular at the time of composition of this text, usually dated to the early Hellenistic period. ${ }^{27}$ As for the rituals performed "on bricks", the referent is even less clear. As was already suggested by Duhm, the Hebrew le benah could be a derogatory description of an altar made of earth. ${ }^{28}$ The ritual is often interpreted as an incense offering, according to the

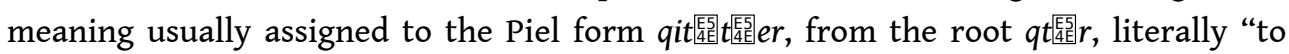
smoke", "to make the smoke go up". ${ }^{29}$ This interpretation is probable, although not certain, as the verb qt医 $r$ elsewhere in the Hebrew Bible refers more generally to the smoke produced by sacrifice. ${ }^{30}$ The Greek text has $\theta u \mu t \alpha \omega^{\prime} \omega$, which is the usual equivalent for qit $t_{45}^{\left[E_{1}\right.} t t_{45}^{[5} e r$ in the Septuagint. While $\theta u \mu t \alpha \omega \omega$, "to burn so as to produce

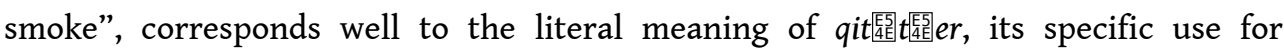
incenses and perfumes is attested in Greek language. Moreover, the Greek translation specifies the recipients of this offering, namely the demons. In this regard, a text-

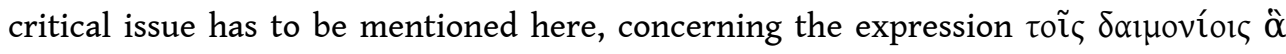
oủ É $\sigma \tau \imath v$ found at the end of verse 3. Some witnesses from the Lucianic tradition have the lection tols olkououv, which could somehow render the Hebrew form hayošbym at the beginning of verse 4, a word which remains untranslated in the old Greek.

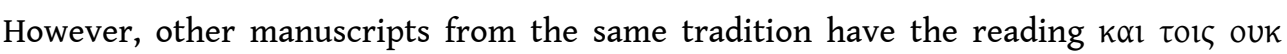

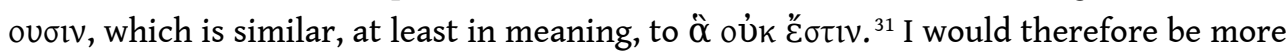

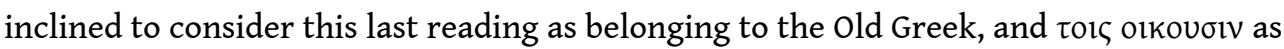
a later correction aiming at reestablishing a text closer to the Hebrew. ${ }^{32}$ In any event, it

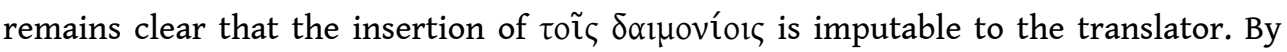
stressing the fact that these demons "do not exist" the translator associates with demons a motif which is proper to the wisdom discourse against idols: the fact that they are powerless. However, while polemics against idol worship insist for the most on their useless materiality, here the deficiency of demons is indicated by their lack of 
substance. ${ }^{33}$ Worshipping idols and demons are further connected in apocryphal traditions, as a late passage from the book of Enoch shows, where demons are paralleled to phantoms ( $\varphi \alpha v \tau \alpha \dot{\alpha} \sigma \mu \alpha \tau \alpha):^{34}$

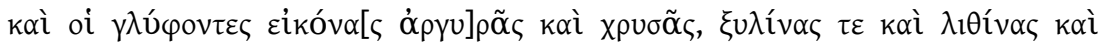

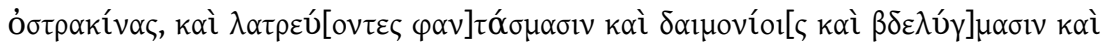

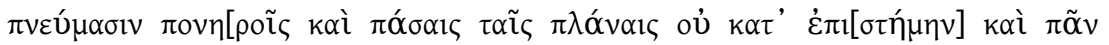

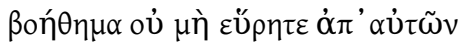

And those who carve images of silver and gold and wood and stone and clay, and worship phantoms and demons and abominations and evil spirits and all errors, not according to knowledge; no help whatsoever you will find from them.

Relevant parallels to the notion of $\delta$ aluóviov as it is shaped in and through the Septuagint can be found in the dialogues of Plutarch. Here we find the idea of $\varphi \alpha \tilde{\nu} \lambda \alpha$ $\delta \alpha \iota \mu$ óva, "bad demons", as a class of malevolent demons clearly distinguished from and inferior to the gods, and which is also held responsible for human diseases or disturbances. ${ }^{35}$ According to Plutarch, the belief that demons have a taste for human sacrifices and human blood is widespread but should not be given any credence. One passage from the life of Pelopidas is explicit in this regard. Here the author speaks of a vision in which Agesilaus, the chief of the Spartan army, was asked to sacrifice his daughter, as Agamemnon had done, in order to ensure the success of his expedition: ${ }^{36}$

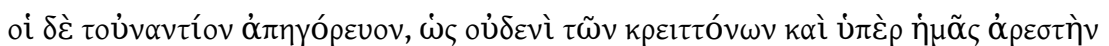

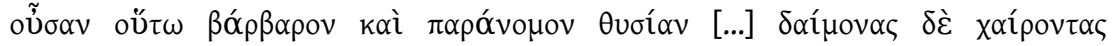

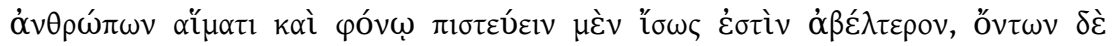

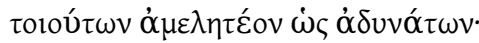

Others, however, argued the contrary, declaring that such a lawless and barbarous sacrifice is not acceptable to any one of the superior beings above us [...] and the belief that demons enjoy human blood and slaughter is equally silly; although such beings should exist, they must be disregarded as ineffective.

13 Here we find two ideas which are equally present in the LXX: that sacrifices (and specifically human sacrifices) are offered to demons, and that demons have no effective power. Moreover, among Greek authors of this period it is not uncommon for foreign gods to be interpreted as "demons": this is the case for Osiris in Plutarch, or for the gods of the Gauls in Strabo. ${ }^{37}$ Again, I wish to stress that I am in no way imagining an influence of the LXX on these writings. Their contexts and their respective interests remain very different, even divergent. However, these parallels point to the fact that we find in the LXX the earliest attestations of a new understanding of a religious notion, which was later widespread in Hellenistic culture. Its language is thus an index of a shared cultural and religious sensibility, which can serve very different purposes. What is unique to the biblical discourse is the vigorous and emphatic way in which the polemic against foreign gods is used to shape identity, and to separate "us" from "others". ${ }^{38}$ This explains the strength of such a discourse, the violence of its tones, as well as the association between the discourse against foreign gods and that against "idols", which is already advanced in the literary context of Deut 32 . Verse 21 represents the core of such a polemic:

They made me jealous with a no-god (lo ' $e l)$,

They provoked me with their worthless practices (behab êêhem),

And I will make them jealous with a no-people.

Here, in Hebrew, foreign gods are explicitly defined as $l \hat{o} ~ ' e l=$ no god, habāalîm, "worthless", parallel to the "no people", the foolish nation that Yhwh is going to send against Israel as rightful punishment for their apostasy. The Greek text reads here: ${ }^{39}$ 


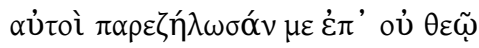

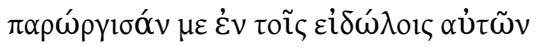

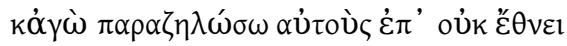

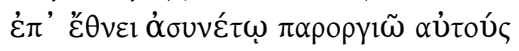

They made me jealous with what is no god,

provoked me with their idols.

So I will make them jealous with what is no people,

provoke them with a people lacking understanding

The repetition of lo' el, lo' Eloha (in Greek: ov $\theta \varepsilon o ́ c)$ at verses 17 and 21, and the reference to the act of provoking God's anger in both verses underline the connection between the two passages. Elt $\delta \omega \lambda \alpha$ at verse 21 seem therefore to perform the same

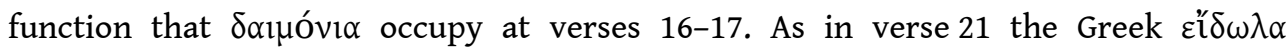
translates the Hebrew habālìm, I will turn now to analyze in what ways these concepts are used in the context of the LXX.

\section{The Gods of the others as E'I $\triangle \Omega \Lambda A$ and as $\triangle$ AIM'ONIA}

As has already been noted by scholars, the translation of he $\underline{b} e l$ with $\varepsilon$ zi $\delta \omega \lambda o v$ is not a literal render (the more literal and most frequent equivalent for hebel in the LXX being $\mu \alpha \tau \alpha 10$ ()). This could be defined as a target-language oriented choice, because here, as in the case of $\delta \alpha \mu$ óviov, the translators returned to an extremely dense, polysemic and operational Greek notion. A particular aspect of the broad semantic range of $\varepsilon i \delta \omega \lambda$ ov could have guided the translator's choice here, namely its inconsistency. Since Homeric times, the word can be applied to anything which is capable of making present something which is elsewhere, or which is not real: an image of someone appearing in dreams (ő $\alpha \rho) ;{ }^{40}$ phantoms or ghosts coming back from the netherworld ( $\left.\psi v x \eta ́\right),{ }^{41}$ or

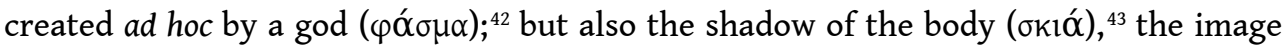
reflected in a mirror, ${ }^{44}$ and so on. These uses stress the fact that the visual

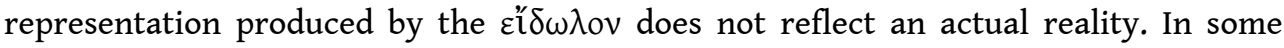
sources, this lack of reality is equated to a lack of body: Lucian defines the shadow of

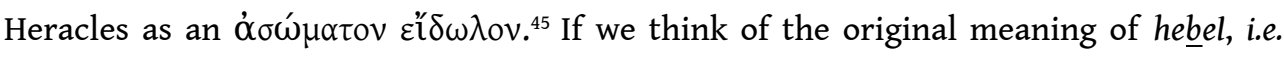
"vapour", from which the idea of "vanity", "uselessness" develops, the translation of habalim with $\varepsilon$ if $\delta \omega \lambda \alpha$ in Deut 32 seems therefore reflect the translator's consciousness that the word $\varepsilon ? ? ? ? ? ?$ can sometimes mean something unsubstantial.í $\delta \omega \lambda$ ov can sometimes mean something unsubstantial. ${ }^{46}$ Moreover, $h \underline{b l}$ and images coming from dreams are already associated in some biblical texts: Zechariah (10:2) condemns dreams as means of divination saying that they offer nothing but a worthless (hebel) comfort, and a difficult passage from Qohelet (5:6), equates h医alômoth ("dreams") with habalîm ("vanities"). ${ }^{47}$ This background could have enhanced the equivalence between $\varepsilon$ k' $\delta \omega \lambda$ ov and he $\underline{b e l}$ found in Deuteronomy. ${ }^{48}$

Whatever the ultimate reason of the translator may have been, in the context of Deut

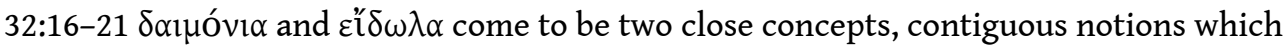
share the feature of being unsubstantial entities. This idea finds parallels in the philosophical Hellenistic literature, as we saw for the representation of demons in Alexander Polyhistor. Plutarch again offers an interesting parallel in the life of the philosopher Dion, who had a vision of a phantom announcing his imminent death: ${ }^{49}$ 


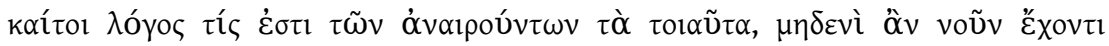

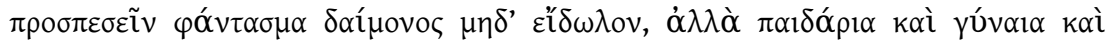

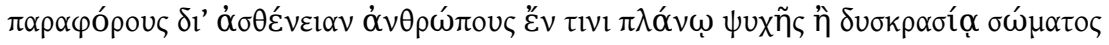

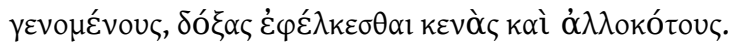

And yet there is the argument of those who refuse such things, (saying that) no man in his right mind was ever visited by a demonic apparition or a spectre, but that little children and women and men deranged by sickness, in some aberration of spirit or bad temperament of the body, have indulged in empty and strange opinions. which these two concepts became interchangeable in the LXX is demonstrated by psalm 95 (= 96 in the Masoretic text) and by its rewriting in the first book of Chronicles, in Chapter 16 (= 1 Paralipomena 16 in the LXX). The psalm focuses on the celebration of Yhwh's royalty, which surpasses that of every other heavenly being. The sovereignty of Yhwh on the other gods is highlighted in various ways, already in the Hebrew version. On the one hand, his superior strength over all the other gods is explicitly affirmed; on the other, the text insists on the ineffectiveness and the vacuity of other divinities in comparison to Yhwh, by saying that "All the gods of the nations are gods of nothing ("elîlim), and Yhwh made the heavens". ${ }^{50}$ The song attributed to David in 1 Chronicles 16 is a rewriting of several psalms, which are combined together in a new composition. Verse 26 quotes directly from Ps 95:5, and in Hebrew the two verses are strictly identical. The name 'elîl is worth of attention in these verses. This form, which appears almost always in the plural, is used in the Hebrew Bible with a pejorative meaning, and it may have been created intentionally for this purpose. The noun is reminiscent of the adjective "elîl, which means "weak", "insignificant", and could polemically recall the

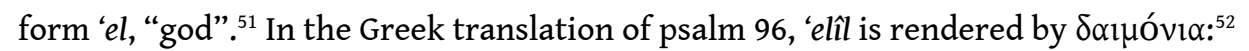

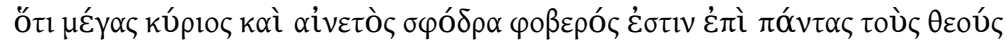

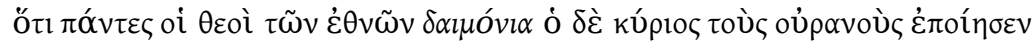

As the great and much praiseworthy lord is terrible over all the gods

Because all the gods of the nations are demons, but the Lord made the heavens.

These "gods of nothing" of the nations can correspond well to demons, according to the logic already at work in Deut 32. However, in the Septuagint of 1 Paral 16:26 there is a difference, as the text reads:

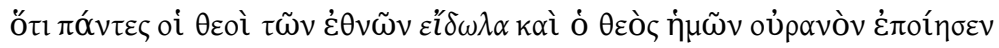

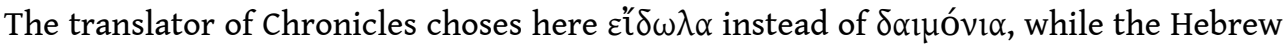
referent 'elîl remains the same ('elîl). Such a difference is not surprising, as the term 'elilim is not translated consistently in the LXX. In fact, a different translation is provided for almost every occurrence. However, all the translations reflect the language of the polemic against idols: sometimes it is rendered by $\beta \delta \varepsilon \lambda \hat{v} \gamma \mu \alpha \tau \alpha$

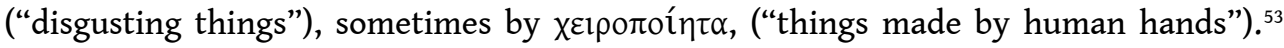
Moreover, the choice made by the translator of Chronicles has an antecedent in Lev 19:4,

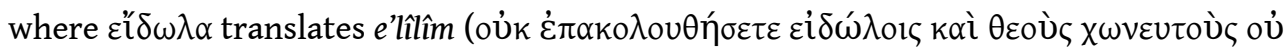

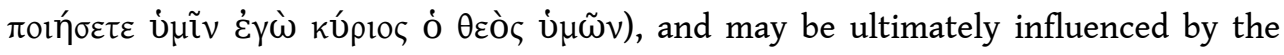
traditions of the Decalogue. ${ }^{54}$ For our purposes, it is relevant to observe that the comparison between the Greek text of Psalms and that of Chronicles attests to a high

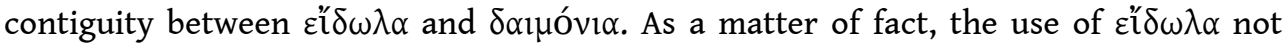
only leads immediately to the larger context of the polemics against the "idols", but also to the interdiction of images, or divine images as it is stated in the Decalogue, and 
to its ancient reception. Before turning to this last point, I would like to make some provisional remarks regarding the relationship between $\delta \alpha \imath$ óvı $\alpha$ and $\varepsilon i \delta \omega \lambda \alpha$ in the LXX.

21 First, the translators selected one specific meaning among those which were inherent to the highly polysemic notions of $\delta \alpha i ́ \mu \omega v$ and $\varepsilon i \delta \omega \lambda$ ov. The success of these

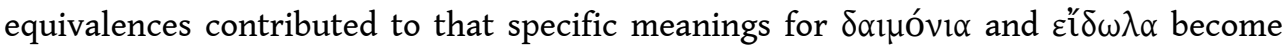
stable within the LXX itself, and this choice will have a considerable impact on the following traditions. The connection between $\delta \alpha \iota \mu o ́ v ı \alpha$ and $\varepsilon \iota \delta \omega \lambda \alpha$ will be taken over and further developed both by Paul and by the author of Revelation..$^{55}$ The association between sacrifices to demons and sacrifices to idols will become a common topos in early Christian discourse. ${ }^{56}$

Second, the appearance of Saluóviov in the LXX of Deut 32 is a source-based choice, based on the šedim of the Vorlage. Yet the literary frame insists on the opposition

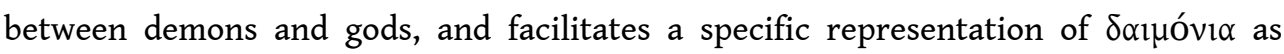
potentially negative beings which do not belong to the "traditional pantheon" and which are clearly distinguished from the latter. Not only does this notion fit the context of Hellenistic literature, but the LXX constitutes, strictly speaking, the earliest evidence of the use of $\delta$ a $\mu$ óviov with this meaning.

Third, in constructing the polemics against foreign gods conceived as $\varepsilon i \delta \omega \lambda \alpha$, the Septuagint translators and later LXX authors exploited a meaning which can sometimes be associated to the Greek term: the idea of insubstantial form, or phantom, stressing the aspect of vacuity and vanity, which correspond to the Hebrew notions of 'elilitm, hebalîm etc. However, this choice implies an important shift in focus from the Greek notion of $\varepsilon$ ' $\delta \omega \lambda$ ov. As the studies of Jean-Pierre Vernant have clearly shown, ${ }^{57}$ the essential feature of the Greek $\varepsilon \not \delta \omega \lambda o v$ is not its unreliability, or its inconsistency as is underlined in the biblical texts. Instead, the $\varepsilon$ t $\delta \omega \lambda$ ov is characterized by the capacity to make present someone or something which is absent, i.e., by performing a representative function, and working as a functional equivalent to the person (and this fits only partially with our notion of "phantom", which remains an improper translation). In this sense $\varepsilon$ " $\delta \omega \lambda$ ov belongs to the sphere of the "double" of an individual identity: it is a "substitute" for the person. The cultural category of "double" is profoundly inherent to the Greek culture, but foreign to the Jewish world.$^{58}$ From this perspective, the term belongs to the semantical field of image and visual representation and can be referred both to an insubstantial image, i.e. to an image that we would qualify as "appearance", and to a concrete object. For example, the statue of Protesilaus (the first dead of the Trojan war) that was made by his wife Laodamia, and secretly loved and honored in her bedroom, functioned precisely as an z' $\delta \omega \lambda$ ov of the husband because it was capable of fulfilling the pothos, the longing deriving from the absence of the men..$^{59}$ Since the main property of the $\varepsilon$ í $\delta \omega \lambda \mathrm{ov}$ is nor its unreality nor its physical similarity to what is represented, but rather its capacity to make visible a presence that inherently belongs to a different, separate, and invisible world, likeness is not an essential feature. For example, even the kolossoi, the rough stone blocks erected for the dead, can be considered as $\varepsilon$ ' $\delta \omega \lambda \alpha$ in the Greek tradition.

In what follows, I will argue that this aspect did not escape some of the Septuagint translators, who were probably more aware of the polysemic nature of the $\varepsilon$ it $\delta \omega \lambda$ v than is usually acknowledged. 


\section{$E^{\prime} \mid \triangle \Omega \wedge A$, images, and idols} internal category in which a varied and differentiated Hebrew lexicon is combined and applied to illicit gods and cultic objects. However, it should be clarified that the concept of idol is already operational within the Hebrew Bible, even though it is not labeled according to a single name or marker, as is the case in the Greek text. Here the socalled polemics against idols reveals a particular way of denigrating foreign gods by reducing them to mere images. ${ }^{60} \mathrm{As}$ is well known, these polemics are ultimately rooted in Exodus 20:4 and Deut 5:8 and their prohibition of making (divine?) images and serving them as if they were the deities themselves. It is precisely within this context that the

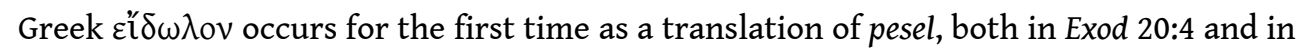
Deut 5:8. However, in Deut 5:8 Alexandrinus and the Chester Beatty papyrus (963) preserve the more literal $\gamma \lambda$ ú $\tau \tau$ tov, "carved object", a reading preferred by Wevers. ${ }^{61}$ Overall, eไ $\delta \omega \lambda$ ov appears more or less 70 times in the Bible, twelve of which are found in the Pentateuch. It translates $15 \mathrm{Hebrew}$ items almost exclusively related to foreign gods or cultic objects, with the exception of teraphîm in the book of Genesis. ${ }^{62}$ In Deuteronomy alone it translates two different items (or three, if we accept the reading of codex Vaticanus): hebalim in 32:21; gyllulìm in 29:16, pesel in Deut 5:8 in Vaticanus and other witnesses. A hypothesis, first proposed by F. Bütschel in the sixties, followed by F. Barnes Tatum, ${ }^{63}$ and still accepted today, is that the introduction of $\varepsilon$ í $\delta \omega \lambda$ ov saw the translator reinterpret the commandment not as anti-iconic but as anti-idolic. ${ }^{64}$ Understood in this way, the prohibition would therefore not concern any divine image, nor any image tout-court, but specifically images of foreign gods, already devalued and reduced to mere "idols". ${ }^{65}$

This hypothesis is based on two observations: first, the fact that the translation of pesel with ह' $\delta \omega \lambda$ ov is unique to these two passages from the Decalogue; second, that the word does not usually designate divine statues or images in the Greek language outside Jewish and Christian writings. Moreover, the meaning of $\varepsilon$ " $\delta \omega \lambda \mathrm{ov}$ as "false" and "deceptive" image is usually substantiated by the pejorative connotation assigned to the word in Platonic writings. In the Platonic theory of imitation and visual arts, Plato opposes the faithfulness of $\varepsilon$ ǐ $\kappa \omega v$ to the deceiving character of $\varepsilon$ ǐ $\delta \omega \lambda o v .{ }^{66}$

However, the interpretation proposed by Bütschel and Barnes Tatum risks reducing the uses of $\varepsilon$ k $\delta \omega \lambda$ ov in the Septuagint to one single logic, and to force all the translations to fit one semantic label. Moreover, the hypothesis does not prove entirely true on closer inspection. In a 2002 article (which unfortunately passed unnoticed among old Testament scholars and historians of Greek religion), Terry Griffith collected a series of literary texts in which $\varepsilon i \delta \omega \lambda$ ov clearly indicates a divine statue or a cultic object. ${ }^{67}$ Other than a passage from Polybius, already known to scholars, he gathered additional evidence from Herodotus, Aesop, but especially from Hellenistic writers, such as Diodorus, Dionysius Halicarnassus, Plutarch and Dioscorides.

Furthermore, a glance at the evidence coming from papyri and inscriptions seems to confirm Griffith's analysis and opens the possibility of taking it even further. A demotic Greek papyrus dating to $87 \mathrm{BCE}$ and coming from Tebt contains a petition by a certain Armisios and his colleagues who work as ibis and hawk embalmers in the temple of 
Hermes. ${ }^{68}$ Armisios complains about someone who struck him and stole the precious garments of the gods while he was washing them. The expression used here is $\tau \tilde{\omega} v \dot{\varepsilon} v$

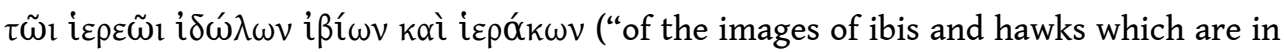

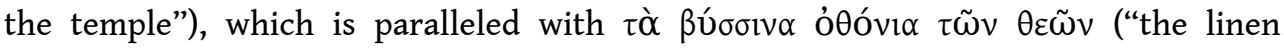
garments of the gods") some lines further on. Eľ $\delta \omega \lambda \alpha$ here indicates the divine statues of the ibis and hawks which are actually meant to represent the gods themselves:

\begin{tabular}{|c|c|}
\hline & $\tau \tilde{\eta} 1 \varepsilon \tau \tilde{\omega} \nu$ \\
\hline & 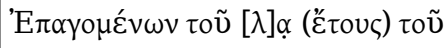 \\
\hline & $\dot{\varepsilon} v o ̀ \varsigma \dot{\eta} \mu \tilde{\omega} v$ A $\rho \mu \imath \sigma_{\sigma l o \zeta} \pi \lambda u_{-}$ \\
\hline & 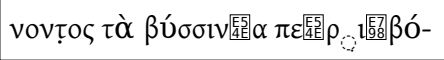 \\
\hline 10 & 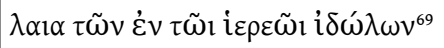 \\
\hline & 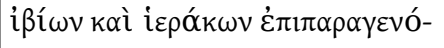 \\
\hline & 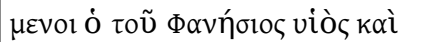 \\
\hline & 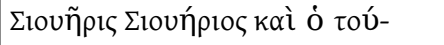 \\
\hline & 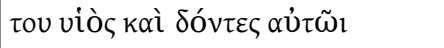 \\
\hline 15 & 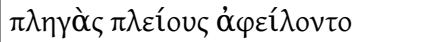 \\
\hline & 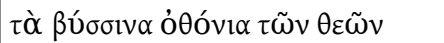 \\
\hline
\end{tabular}

in the fifth of the intercalary days of the year 31, while one of us, Harmiysis, was washing the linen garments of the sacred images of ibises and hawks which are in the temple, the son of Phanesis, Sioueris, son of Sioueris, and his son suddenly appeared, and after having hit him several times they stole the linen clothes of the gods.

Moreover, an ostracon from the cemetery of sacred fish in Latopolis, dating to I-II AD, brings an oracular petition addressed to Athena from Ammonios and his colleagues, ram-embalmers, who have been unfairly accused..$^{70}$ The petition is addressed to the

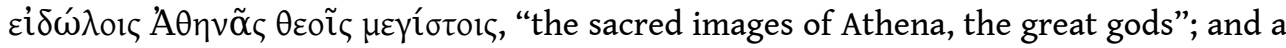

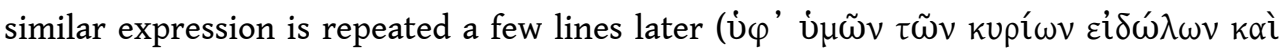

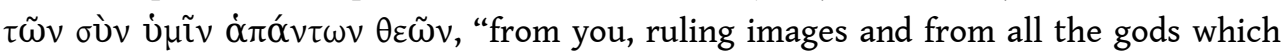
are with you"):

\begin{tabular}{|c|c|}
\hline & 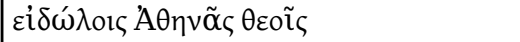 \\
\hline & 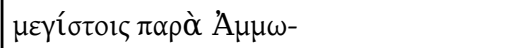 \\
\hline & 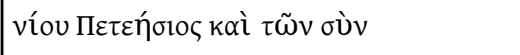 \\
\hline & 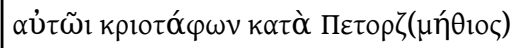 \\
\hline 5 & 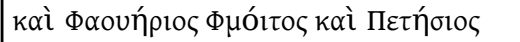 \\
\hline & $\pi \alpha \nu \tau 0 \pi \hat{\omega} \lambda(\mathrm{ov}) \cdot \dot{\alpha} \xi$ เoṽ $\mu \varepsilon \nu \dot{\eta} \mu \tilde{\alpha} \varsigma$ \\
\hline & 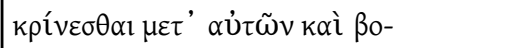 \\
\hline & $\eta \theta \varepsilon \tilde{\sigma} \sigma \theta \alpha \iota \dot{v} \varphi^{\prime} \dot{U} \mu \tilde{\omega} \nu \tau \tilde{\omega} \nu$ \\
\hline
\end{tabular}




\begin{tabular}{|c|c|}
\hline & 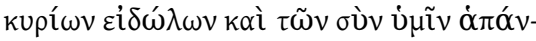 \\
\hline 10 & 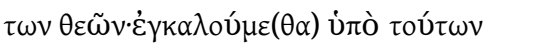 \\
\hline & 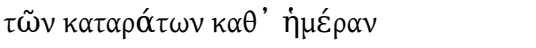 \\
\hline & $\dot{v} \mu \tilde{\omega} v$ \\
\hline
\end{tabular}

to the sacred images of Athena, (the) great gods, from Ammonius son of Peteesis and from his colleagues, the ram-embalmers, against Petorzmethis and Phaoueris, sons of Phmoitis and Petesis, the huckster. We ask you to be judged with them and to receive help from you, ruling images, and from all the gods which are with you. We are accused by these abominable people in your (sacred) day.

In the absence of more information concerning the context of this passage, it remains difficult to establish what exactly these $\varepsilon$ k' $\delta \omega \lambda \alpha$ of Athena were. But the term must refer to some concrete object which represents the goddess in order for the petition to be effective. We know that in Latopolis the Egyptian goddess Neith was assimilated to Athena quite early on; the fish latos (lates niloticus) was considered sacred to her and a cult was devoted to the animal. It is therefore possible that the petition was addressed to the fish itself, which was considered a substitute for the goddess. Further support for this interpretation comes from another papyrus from Tebt, dating back to the first half of the 1st century AD. ${ }^{71}$ The text reports an oath by a corporation of fishermen who swear not to catch the oxyrynchus and the lepidotos, two fishes sacred to Osiris. What is interesting for our purposes is the formulation, which introduces the expression

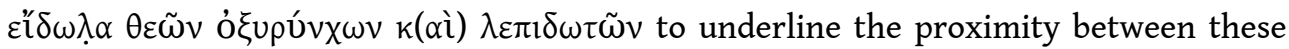
fish and the gods themselves:
We [....] all thirteen being elders of the fishermen of the villages of Narmouthis and Berenicis Thesmophori, swear, all fourteen, to the agents of Sarapion son of Ptolemaeus, nomarch and superintendent of the revenues and the distribution of imposts of the Arsinoite nome, by Tiberius Claudius Caesar Augustus Germanicus Imperator that we never have been or will be privy to fishing or dragging a net or casting a net to catch the images of the divine oxyrhynchi and lepidoti, in conformity with

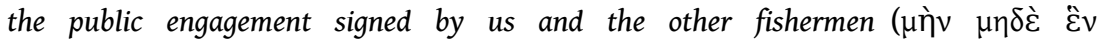

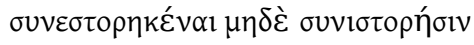

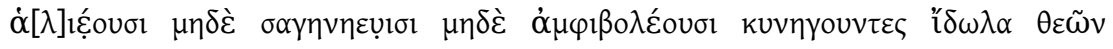

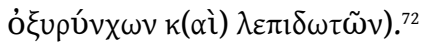

Finally, an inscription of the late 3rd or early 2nd century BCE, coming from a very different context, confirms that $\varepsilon$ i $\delta \omega \lambda$ ov can easily refer to a statue. In the Aretalogy of Sarapis from Delos, the Egyptian priest Apollonios thanks the god Sarapis for the victory over his enemies, specifically some Delian people who brought a lawsuit against him and tried to stop the installation of a temple for the god. The victory is attributed to the power of Sarapis, and is celebrated with a poem which imitates Homeric poetry. The conclusion of the poem describes how, on the day of the trial, Sarapis performed a miracle in which he paralyzed Apollonios' accusers at the trial and rendered them unable to speak. ${ }^{73}$ The text says that they "stood like statues struck by the god or like

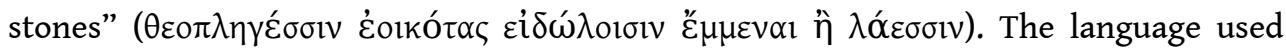

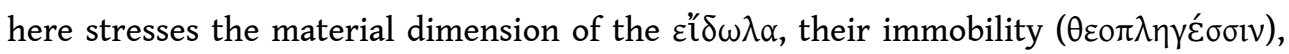

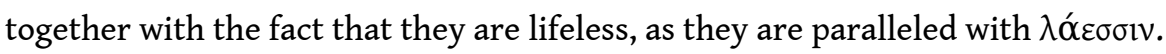

Based on this evidence, we can reasonably argue that in Exod 20:4 č $\delta \omega \lambda$ ov may not yet mean "idol" in some abstract or polemical way. Instead, it renders the idea of a 
material object (image or statue) whose function is to work as a "substitute" for the deity. ${ }^{74}$ In this sense, this choice points towards a specific reception of the second commandment, which was open to different interpretations still during Hellenistic and Roman times. ${ }^{75}$ In the LXX formulation, the equivalence between pesel and $\varepsilon$ í $\delta \omega \lambda \mathrm{v}$ respects both the Hebrew text (source language) and the Greek language of the time (target language).

\section{Conclusions}

33 I would like to conclude by pointing to some of the implications of the present study, which concern the interpretation of the category of "demon" and "idol" within the Septuagint and in ancient Jewish traditions on the one hand, and the role of the Septuagint vis-à-vis Greek religion, on the other.

Regarding the notion of $\varepsilon$ í $\delta \omega \lambda$ ov, the evidence analyzed suggests that there was no one overarching semantics of $\varepsilon$ t $\delta \omega \lambda$ ov in all the books of LXX, but rather that the translators were aware of the multiple meanings and "nuances" of the word. The examples from Exodus and Deuteronomy show that the translators exploited these different connotations by selecting a specific meaning or aspect of meaning in specific instances, according to what they considered the best fit for that context.

As for the relationship between $\varepsilon 1 \delta \omega \lambda \alpha$ and "idols", it is undeniable that the LXX is the context in which a certain notion of "idol" was fashioned and passed on to the New Testament and early Christian literature. However, this religious construction operates more on the level of the development of the inner LXX tradition, as it is attested in later books such as Isaiah or Daniel, and especially in non-translated books, such as Wisdom or Maccabees. Therefore, the discussion of idols and the relationship between idols and images needs to be revised and reframed in several regards, both in relation to the Hebrew Bible and to the Septuagint. On the one hand, a common discourse against the idols seems to develop already in the Hebrew Bible itself, although without a single term yet emerging. On the other hand, Septuagint translators, and more specifically the translators of the Pentateuch seem to have been well aware of the broad semantic spectrum covered by $\varepsilon$ č $\delta \omega \lambda$ ov in Greek. In this regard, the specificity of the LXX and its originality seem to reside elsewhere: namely, in having joined together the polemic against idols and a polemic against demons and demon-sacrifices. In doing this, Greek translators played a considerable role in redefining the category of demon vis-à-vis the Greek world.

More generally, the relationship between $\varepsilon i \delta \omega \lambda \alpha$ and divine images calls for a reexamination of the entire vocabulary of images in the LXX, and the relationship between divine (or cultic) and non-cultic images against the background of Hellenistic papyri. In this regard, the influence of Platonic theories has to be reconceived, or even downsized, not only when it comes to the LXX but, more generally, in the study of image-related vocabulary during Hellenistic times.

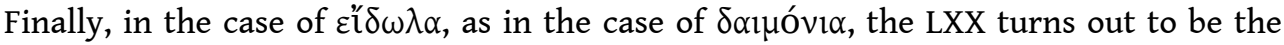
earliest witness of a religious terminology that will become more widespread in several non-Jewish contexts. This demonstrates, once again, not only the contribution of the Septuagint and the Septuagint lexicography to the study of Jewish Hellenistic religion, 
but also, on a larger scale, the interest of the Septuagint for a better understanding of the Hellenistic religious world.

\section{BIBLIOGRAPHY}

S. ACKERMAN, Under Every Green Tree: Popular Religion in Sixth-century Judah, Winona Lake, 2001²[1992] (Harvard Semitic Monographs, 46).

J. AITKEN, “Outlook,” in E. BONS, R. BRUCKER, J. JOOSTEN (eds.), The Reception of Septuagint Words in Jewish-Hellenistic and Christian Literature, Tübingen, 2014 (WUNT, 367), p. 183-194.

S. AMMANN, Götter für die Toren: die Verbindung von Götterpolemik und Weisheit im Alten Testament, Berlin, 2015 (Beihefte zur Zeitschrift für die alttestamentliche Wissenschaft, 466).

S. ANDERSON, Idol Talk: The Discourse of False Worship in the Early Christian World, PhD Dissertation, Yale University, 2016.

A. ANGELINI, “L'imaginaire comparé du démoniaque dans les traditions de l'Israël ancien. Le bestiaire d'Esaïe dans la Septante," in T. RÖMER, B. DUFOUR, F. PFITZMANN (eds.), Entre dieux et hommes: anges, démons et autres. Actes du colloque organisé par le Collège de France, Paris, les 19-20 mai 2014, Fribourg/Göttingen, 2017 (OBO, 286), p. 116-134.

-, "Demonic agents in the Greek Bible. Evaluating the role of the Septuagint in creating a Hellenistic demonology," in M. GEIGER et al. (eds.), Die Septuaginta-Geschichte, Wirkung, Relevanz. 6. Internationale Fachtagung veranstaltet von Septuaginta Deutsch (LXX.D), Wuppertal 21.-24. Juli 2016, Tübingen, 2018, p. 701-713.

I. ASSAN-DOTE, J. MOATTI-FINE, Baruch, Lamentations, Lettre de Jérémie, Paris, 2005 (La Bible d'Alexandrie, 25.2).

D.A. BAER, When We All Go Home: Translation and Theology in LXX Isaiah 56-66, Sheffield, 2001 (Hebrew Bible and Its Versions).

D. BARBU, Naissance de l'idolâtrie: image, identité, religion, Liège, 2016 (Religions. Comparatisme Histoire - Anthropologie, 7).

W. BARNES TATUM, “The LXX Version of the Second Commandment: A Polemic against Idols, not Images," Journal for the Study of Judaism 17/2 (1986), p. 177-195.

M. BETTINI (ed.), La maschera, il doppio, il ritratto. Strategie dell'identità, Bari, 1991.

M. BETTINI, Il ritratto dell'amante, Torino, 1992.

J. BLENKINSOPP, Isaiah 56-66: A New Translation with Introduction and Commentary, New York, London, 2003 (Anchor Bible, 19B).

C. BONNET, “Échos d'un rituel de type adonidien dans l'oracle contre Moab d'Isaïe (Isaïe, 15)," Studi Epigrafici e Linguistici 4 (1987), p. 101-119.

B. BoyAVAL, “Note sur des pièces d'archives lilloises," CdE 55 (1980), p. 309-313. 
F. BRENK, In Mist Apparelled: Religious Themes in Plutarch's Moralia and Lives, Leiden, 1977 (Mnemosyne, suppl. 48).

F. BRENK, “Genuine Greek Demons, 'In Mist Apparelled'? Hesiod and Plutarch,” in ID. (ed.), Relighting the Souls: Studies in Plutarch, in Greek Literature, Religion and Philosophy, and in the New Testament Background, Stuttgart, 1998, p. 170-181.

L. BRICAULT, Recueil des inscriptions concernant les cultes Isiaques (RICIS), Paris, 2005.

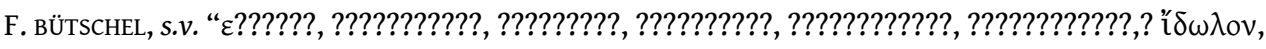

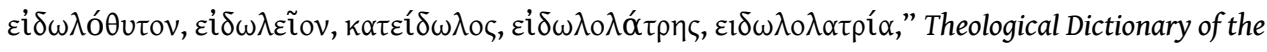
New Testament II (1964), p. 376-380.

P. CHANTRAINE, "Le divin et les dieux chez Homère", in La notion du divin depuis Homère jusqu'à Platon: sept exposés et discussions, Vandœuvres/Genève, 1954 (Entretiens sur l'Antiquité classique, 1), p. 47-79.

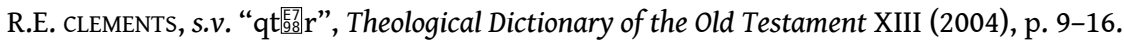

R. CRIBIORE, Gymnastics of the Mind: Greek Education in Hellenistic and Roman Egypt, Princeton, 2001.

E. DAFNI, "Genesis 1-11 und Platos Symposion. Überlegungen zum Austausch von hebräischem und griechischem Sprach- und Gedankengut in der Klassik und im Hellenismus," Old Testament Essays 19/2 (2006), p. 584-632.

M. DELCOR, "Le Problème des jardins d'Adonis dans Isaïe 17,9-11 à la lumière de la civilisation syro-phénicienne," Syria 55 (1978), p. 371-394.

M. DETIENNE, La notion de daimôn dans le pythagorisme ancien, Paris, 1963.

B. DUHM, Das Buch Jesaia, Göttingen, $1922^{4}$.

R. DUPERTUIS, "Writing and Imitation: Greek Education in the Greco-Roman World," Forum 1/1 (2007), p. 3-29.

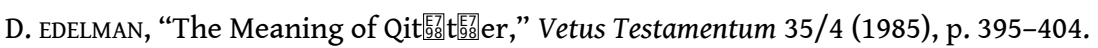

O. EISSFELDT, Adonis und Adonaj, Berlin, 1970 (Sitzungsberichte der Sächsischen Akademie der Wissenschaften zu Leipzig, Philologisch-historische Klasse, 115.4).

A. EVEN SHOSHAN, Ha millon chadash, Jerusalem, 1984 [hebr.].

G. FRANÇOIS, Le polythéisme et l'emploi au singulier des mots « theos » et "daimōn » dans la littérature grecque d'Homère à Platon, Paris, 1957 (Bibliothèque de la Faculté de philosophie et lettres de l'Université de Liège, 147).

C. FREVEL, K. PYSCHNY, "Perserzeitliche Räucherkästchen: Zu einer wenig beachteten Fundgattung im Kontext der These E. Sternsin," in C. FREVEL, K. PYSCHNY, I. CORNELIUS (eds.), A “Religious Revolution" in Yêhud?: The Material Culture of the Persian Period as a Test Case, Fribourg/Göttingen, 2015 (OBO, 267), p. 111-220.

F. FRONTISI-DUCROUX, “Du simple au double,” Revue d'Esthétique 1 (1980), p. 111-130.

-, Du masque au visage. Aspects de l'identité en Grèce ancienne, Paris, 1995.

W. FURLEY, "Revisiting Some Textual Problems in the Delian Sarapis Aretalogy by Maiistas (IG XI 4 No. 1299)," ZPE 180 (2012), p. 117-125.

G. GALLAZZI, “Supplica ad Atena su un ostrakon da Esna,” ZPE 61 (1985), p. 101-109.

R. GARLAND, Introducing New Gods, London, 1991. 
J. GASCOU, "Justice d'Athéna en Egypte Romaine," in F. HOOGENDIJK et al. (eds.), Sixty-five Papyrological Texts: Presented to Klaas A. Worp on the Occasion of his 65th Birthday, Leiden, 2008 (Papyrologica Lugduno-Batava, 33), p. 29-39.

A. GEORGIADOU, Plutarch's Pelopidas: A Historical and Philological Commentary, Stuttgart, 1997 (Beiträge zur Altertumskunde, 105).

D.G. GREENBAUM, The Daimon in Hellenistic Astrology: Origins and Influence, Leiden, 2016.

T. GRIFFITH, "EIDOLON as 'Idol' in Non-Jewish and Non-Christian Greek," The Journal of Theological Studies 53/1 (2002), p. 95-101.

R. HAYWARD, "Observations on Idols in Septuagint Pentateuch," in S. BARTON (ed.), Idolatry: False Worship in the Bible, Early Judaism and Christianity, London, 2007, p. 40-57.

P. HEGER, The Development of Incense Cult in Israel, Berlin/New York, 1997 (Beihefte zur Zeitschrift für die Alttestamentliche Wissenschaft, 245).

D. HILLERS, E. CUSSINI, Palmyrene Aramaic Texts, Baltimore/London, 1996.

M. JASTROW, A Dictionary of the Targumim, the Talmud Babli and Yerushalmi, and the Midrashic Literature, London/New York, 1926.

T. KAIZER, "De Dea Syria et aliis deabusque: A Study of the Variety of Appearances of Gad in Aramaic Inscriptions and on Sculptures from the Near East in the First Three Centuries AD (Part 1)," Orientalia Lovaniensia Periodica 28 (1997), p. 147-166.

-, "De Dea Syria et aliis deabusque: A Study of the Variety of Appearances of Gad in Aramaic Inscriptions and on Sculptures from the Near East in the First Three Centuries AD (Part 2)," Orientalia Lovaniensia Periodica 29 (1998), p. 33-62.

L. KOEHLER, W. BAUMgARTNER, The Hebrew and Aramaic Lexicon of the Old Testament, Leiden/New York, 1994.

J.L. KOOLE, A. RUNIA, Isaiah. Part 3, Kampen, 1997 (Historical Commentary on the Old Testament). R. KOTANSKY, J. NAVEH, S. SHAKED, “A Greek-Aramaic Silver Amulet from Egypt in the Ashmolean Museum,” Le Museón 105 (1992), p. 5-25.

N. LEVTOW, Images of Others: Iconic Politics in Ancient Israel, Winona Lake, 2008 (Biblical and Judaic studies, 11).

A. LE BOULLUEC, P. SANDEVOIR, La Bible d'Alexandrie. 2: L'Exode, Paris, 1989.

V. LONGO, Aretalogie nel mondo greco. Vol. I : epigrafi e papiri, Genova, 1969.

T. VAN DER LOUW, Transformations in the Septuagint: Towards an Interaction of Septuagint Studies and Translation Studies, Leuven, 2007 (Contributions to Biblical Exegesis and Theology, 47).

V. MANKOWSKI, Akkadian Loanwords in Biblical Hebrew, Winona Lake, 2000.

L. MARTI, “Anges ou démons ? Les êtres divins vus par les savants assyriens," in T. RÖMER et al. (eds.), Entre dieux et hommes : Anges, démons et autres figures intermédiaires. Actes du Colloque organisé par le College de France, Paris, les 19 et 20 Mai 2014, Fribourg/Göttingen, 2017 (OBO, 286), p. 41-59.

M. VAN DER MEER, “Anthropology in the Ancient Greek Versions of Gen 2:7," in J. RUITEN, G. VAN KOOTEN (eds.), Dust of the Ground and Breath of Life Gen 2:7. The Problem of a Dualistic Anthropology in Early Judaism and Christianity, Leiden, 2016, p. 36-57.

T. MORGAN, Literate Education in the Hellenistic and Roman Worlds, Cambridge, 1998. 
J. NAVEH, S. SHAKED, Amulets and Magic Bowls. Aramaic Incantations of Late Antiquity, Third Edition, Jerusalem, 1998.

K. NIELSEN, Incense in Ancient Israel, Leiden, 1986 (Supplements to Vetus Testamentum, 38).

H. NOWAK, Zur Entwicklungsgeschichte des Begriffes Daimon: Eine Untersuchung epigraphischer Zeugnisse vom 5. Jh. v. Chr. bis zum 5. Jh. n. Chr., Bonn, 1960.

E. PACHоUмI, The Concepts of the Divine in the Greek Magical Papyri, Tübingen, 2017 (Studies and Texts in Antiquity and Christianity, 102).

V. PIANO, Il Papiro di Derveni tra religione e filosofia, Firenze, 2016 (Studi e testi per il Corpus dei papiri filosofici greci e latini, 18).

V. PIRENNE-DELFORGE, “Éros en Grèce : dieu ou démon ?" in J. RIES, H. LIMET (eds.), Anges et démons : Actes du Colloque de Liège et de Louvain-la-Neuve, 25-26 novembre 1987, Louvain-la-Neuve, 1989 (Homo religiosus, 14), p. 223-239.

F. PREISIGKE, Griechische Papyrus der Universitäts- und Landesbibliothek zu Strassburg, Leipzig, 1920.

H. PREUSS, s.v. “'elîl,” Theological Dictionary of the Old Testament I (1977), p. 285-287.

S. RIBICHINI, s.v. "Adonis," in K. VAN DER TOORN, B. BECKING, P. VAN DER HORST (eds.), Dictionary of Deities and Demons in the Bible (DDD), Leiden/Boston/Köln, 1999, p. 7-10.

-, s.v. "Gad," ibid., 1999, p. 339-341.

M. RöSEL, Übersetzung als Vollendung der Auslegung: Studien zur Genesis-Septuaginta, Berlin, 1994 (Beihefte zur Zeitschrift für die Alttestamentliche Wissenschaft, 223).

S. SAÏD, “Deux noms de l'image en grec ancien : idole et icône,” CRAI 131.2 (1987), p. 309-330.

J. SCHAPER, "God and the Gods: Pagan Deities and Religious Concepts in the Old Greek of Isaiah," in K. DELL, G. DAVIES, Y. КоH (eds.), Genesis, Isaiah and Psalms. A Festschrift to Honour Professor John Emerton for His Eightieth Birthday, Leiden, 2010, p. 135-152.

I. SEELIGMAN, The Septuagint Version of Isaiah: A Discussion of Its Problems, in R. HANHART, H. SPIECKERMANN (eds.), The Septuagint Version of Isaiah and Cognate Studies, Tübingen, 2004 (Forschungen zum Alten Testament, 40), p. 119-294 [=1948].

G. SFAMENI GASPARRo, "Daimôn and Tychê in the Hellenistic Religious Experience," in P. BILDE (ed.), Conventional Values of the Hellenistic Greeks, Aarhus, 1997, p. 66-109.

G. SFAMENI GASPARRO, Problemi di religione greca ed ellenistica. Dèi, dèmoni, uomini: tra antiche e nuove identità, Cosenza, 2009.

-, "Daimonic Power", in E. EIDINOW, J. KINDT (eds), The Oxford Handbook of Ancient Greek Religion (Oxford handbooks online), Oxford, 2015, p. 413-427.

M. SокоLOFF, A Dictionary of Jewish Babylonian Aramaic of the Talmudic and Geonic Periods, Ramat-Gan/ Baltimore/London, 2002.

-, A Dictionary of Jewish Palestinian Aramaic of the Byzantine Period, Third Revised and Expanded ed., Ramat Gan, 2017.

L. STUCKENBRUCK, "Demonic Beings and the Dead Sea Scrolls," in I. FRÖHLICH, E. KOSKENNIEMI (eds.), Evil and the Devil, London, 2013 (ISCO and LNTS, 481), p. 51-70 [repr. in The Myth of Rebellious Angels. Studies in Second Temple Judaism and New Testament Texts, Tübingen, 2014, p. 78-102]. 
A. тімотіN, La Démonologie platonicienne : histoire de la notion de « daimōn » de Platon aux derniers néoplatoniciens, Leiden/Boston, 2012 (Philosophia Antiqua, 128).

M. VAN DER VORM-CROUGHS, The Old Greek of Isaiah: An Analysis of Its Pluses and Minuses, Atlanta, 2014 (Society of Biblical Literature Septuagint and Cognate Studies, 61).

J.-P. VERNANT, "Figuration de l'invisible et catégorie psychologique du double : le colossos," in Mythe et pensée chez les Grecs. Étude de psychologie historique, Paris, 1965, p. 251-264.

-, "Image et apparence dans la théorie platonicienne de la mimesis," in Religions, histoires, raisons, Paris, 1979, p. 105-137 [= Journal de Psychologie 2 (1975)].

-, "De la présentification de l'invisible à l'imitation de l'apparence," in Image et signification.

Rencontres de l'École du Louvre, Paris, 1983, p. 25-37.

-, "Figuration et image," Mètis 5 (1990), p. 225-238.

H.S. VERSNEL, “Beyond Cursing: An Appeal to Justice in Judicial Prayers," in C. FARAONE, D. OBBINK (eds.), Magika Hiera: Ancient Greek Magic and Religion, New York/Oxford, 1991, p. 60-106.

W. vON SODEN, Akkadisches Handwörterbuch, 3 vol., 1965-1974, Wiesbaden, 1965.

J.D. WATTS, Isaiah 34-66, Waco (TX), 1987 (Word Biblical Commentary, 25).

K. WESTERMANN, Das Buch Jesaja: Kapitel 40-66, Göttingen, 1966 (Das Alte Testament Deutsch, 19).

J. WEVERS, Septuaginta: Vetus Testamentum graecum. Vol. 3, 2, Deuteronomium, Göttingen, 1977.

A. WILHELM, "Zu den Urkunden der Ptolemäerzeit und anderen Papyri," Akademie der Wissenschaften in Wien, Anzeiger 74. Jahrgan 1937 (1938), p. 69-92.

J. ZIEGLER, Septuaginta: Vetus Testamentum graecum. Vol. 14, Isaias, Göttingen, 1939.

H. ZIMMERN, Akkadische Fremdwörter als Beweis für Babylonischen Kultureinfluss, Leipzig, 1917.

\section{NOTES}

1. For a list of occurrences, see BARBU (2016), p. 45.

2. "Masoretic text".

3. The second major context where most of the occurrences of $\delta$ aı book of Tobit, which constitutes under several regards a separate corpus. Other contexts of usage are represented by Ps 90:6 (= $91 \mathrm{MT}$ ), and two passages from Isaiah (Isa 13:21 and 14:34) which are discussed respectively in ANGELINI (2018) and (2017).

4. On the probability that the extant Greek text of Baruch was translated from a Hebrew version see ASSAN-DHOTE and MOATTI-FINE (2005), p. 55-56 and p. 69-71.

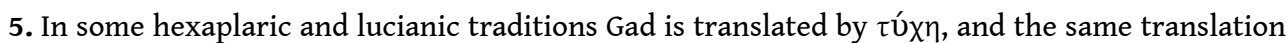
is suggested by Aquila, Simmachus and Theodotion: see ZIEGLER (1939), apparatus. Although an explicit equivalence between Gad and Tyche is found only in one bilingual inscription from Palmyra (CIS II $3927=0273$ HILLERS AND CUSSINI [1996]), the proximity between these two deities during Hellenistic and Roman times is well demonstrated by KAIZER (1997) and (1998), p. 58-60. On the West-Semitic background of Gad see RIBICHINI (1999), p. 339-341.

6. Deut 32:16-17 (MT). Unless otherwise indicated, all translations are mine.

7. ZIMMERN (1917), p.69; VON SODEN (1965-1974), vol. 3, p. 1208; KOEHLER-BAUMGARTNER (1994), s.v.; MANKOWSKI (2000), p. 138.

8. CAD 17/2, s.v. šedu; MARTI (2017), p. 46-48. 
9. 4Q510 1:5-8; 4Q511 10:1-5 (DJD 7), 11Q11 (DJD 23); 4Q196 :14; 4Q197:4 (DJD 19). For a classification of the occurrences found in the Dead Sea Scrolls see STUCKENBRUCK (2013) [= 2014], p. 85-87.

10. NAVEH and SHAKED (1998): bowls n. $1 ; 2 ; 8 ; 5 ; 10 ; 13$; amulets n. 7; 7b; 13. KOTANSKY, NAVEH and SHAKED (1992), 1. 11, 13, 17, p. 8-9 (= SEG 42,1582). Peshitta reads šydh in Lev 17:7 for the Hebrew s'yrm (boucs).

11. E.g. Targum Onqelos on Lev 17:7; Targum Onqelos and Neofiti on Deut 32:17; Targum Pseudo-Jonathan on Deut 32:10; Targum Jonathan on Isaiah 13:21.

12. JASTROW (1903), p. 1523-1524; EVEN SHOSHAN (1984), s.v.

13. The literature on $\delta \alpha i ́ \mu \omega v$ in various ancient corpora is vast. Among several publications one can refer to CHANTRAINE (1954), FRANÇOIS (1957), DETIENNE (1963), NOWAK (1960); BRENK (1977) and (1986), PIRENNE-DELFORGE (1989), and, more recently: TIMOTIN (2012), GREENBAUM (2016), PACHOUMI (2017).

14. SFAMENI GASPARRO (1997), (2009), (2015).

15. Pythagorean Commentaries, ap. Alexander Polyhisthor, in Diogenes Laertius 8.32 [ed. DELATTE, trad. SFAMENI GASPARRO (1997), slightly modified]; for a distinction between gods, daimones and humans attributed to Pythagoras see ibid. 8.23, and for a comment on this passage see DETIENNE (1963), p. 32-37.

16. Works, 112-123.

17. SDGI II $1582 \mathrm{~A}$.

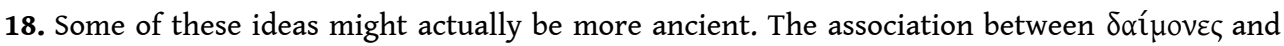

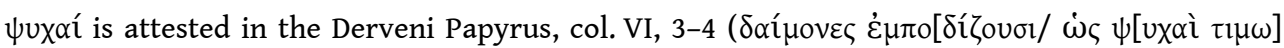
poì, ed. PIANo [2016]). For the immateriality of the $\psi u x \alpha i ́$ see e.g. Hippocrates, On Diet, 29 (Littré 6, p. 504-505); Plato, Phaedon, 114b-c.

19. On the possible exception represented by Isa 65:11 see infra, footnote 24 .

20. For example, Bacchae, 894; The Phoenician Women, 352. See FRANçoIs (1957), p. 53 and 313.

21. Plato, Apology, 24c.

22. See on this GARLAND (1992), p. 145-150.

23. The possibility of a Platonic influence on LXX translators and more specifically on the translators of the Pentateuch is a debated issue. While RöSEL (1994) and DAFNI (2006) believe that some Pentateuchal translators actively engaged with platonic philosophical theories, others suggest more caution (see VAN DER LOUW [2007], p. 83-84; VAN DER MEER [2016]). Actually, there is some papyrological evidence for Plato's presence at the highest levels of education during late Hellenistic and Roman times (see DUPERTUIS [2007], p. 8-11). Moreover, a dialogue with platonic ideas is recognizable in the writings of Philo and of authors of later Septuagint books, like the book of Wisdom. A text like 2 Maccabees 6 shows an influence of the Socratic ideal of heroic death. However, the projection of direct engagement with Plato's Apology back to the translators who were active in the 3rd c. BCE remains doubtful. Despite the popularity of Socrates as a character in Hellenistic times, The Apology of Socrates was not a school text. On the "basic package" of Greek education in Greco-Roman Egypt, which included Homer, Hesiod, Euripides, Menander and few passages from Isocrates, see MORGAN (1998), p. 67-73; CRIBIORE (2001), p. 178-205.

24. A partly different case could be made for the LXX of Isa 65:11, where the text polemicizes against those who "prepare the table for the demon and fill a mixed drink for Tyche." While

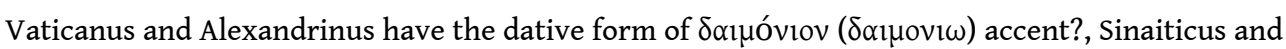
other witnesses from the Alexandrinus group have $\delta \alpha i ́ \mu o v$, derived from $\delta \alpha i ́ \mu \omega v$. See zIEGLER (1939), p. 361, apparatus. This reading is also preferred by Rahlfs. Here, as has been suggested by SEELIGMANN (1948), p. 99-100, and reaffirmed more recently by SCHAPER (2010), it is probable that the translator interpreted the sacrifices offered to Gad and Meni in the Hebrew text as a reference to the cult of "Good Fortune" and "Good demon" (agathodaimon), which were extremely 
popular in Hellenistic and Roman times in Egypt and through the Levant. While remaining within the polemics against foreign gods, in this specific case the translator is not reducing them to "demons" as in the other passages. Instead, he is directly referring to the Hellenistic cults of

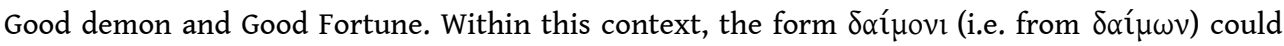
therefore be original to the old Greek.

25. See e.g. Deut 4:25; 9:18; 31:29, compare also Psa 78:58 (= 77:58 LXX).

26. So ACKERMAN $\left(2001^{2}\right)$ [1992], p. 165-212. Compare also Isa 66:17.

27. So EISSFELDT (1970), p. 19-20. Tammuz is already named in Ezekiel 8:14. See on this RIBICHINI (1999) (Adonis), p. 9. For other references to Adonis-Tammuz in the book of Isaiah, see DELCOR (1978) (Isaiah 17), BONNET (1987) (Isaiah 15).

28. DUHM (1892), p. 475; followed by WESTERMANN (1966), p. 318.

29. So WESTERMANN (1966), p. 318; WATTS (1987), p. 339; ACKERMAN $\left(2001^{2}\right)$ [1992], p. 169-174; KOOLE (2001), p. 414; BLENKINSOPP (2003), p. 266-267.

30. The sequence $z b h{ }_{45}^{\left[E_{E}\right.}+q t{ }_{45}^{\left[{ }_{4}^{5}\right.} r$, which occurs often as a pair in the Hebrew Bible, is usual understood to refer to two different ritual actions (the sacrifice and the burning of incense). However, Diana Edelman has raised the possibility that these verbs indicate two subsequent phases of a same ritual, namely the slaughtering of the animal and the burning of the meat (see EDELMAN [1985]). According to R. Clements (TDOT 2004, s.v. $q t^{\left[{ }_{45}\right.} r$ ) the root $q t^{\left[E_{15}\right.} r$ is specialized for "incense offering" in the Hiphil form, but in several cases, as in Isa 65:3, there is a Piel: therefore, his distinction does not seem to be so sharp. Moreover, in Isa 65:3, most commentators accept the meaning of "burning incense" based on a parallel with an inscription from Lachish, where lbnt would mean "incense altar". Then, lebēnîm in Isa 65:3 would not mean "brick", but "incense altar" (ACKERMAN [2001², 1992], p. 179-184; BLEKINSOPP [2003], p. 271). But the meaning of lbnt as "incense altar" on the inscription is improbable (see NIELSEN [1986], p. 48 and, more recently, FREVEL and PSYCHNY [2014], p. 163-164). A better key to understand the meaning of $q$ t卧 $r$ is provided by comparative philology and semantics. First, in other Semitic languages the verb qt specialized meaning of "burning incense" beside the more general meaning (See qat医 Akkadian, vON SODEN [1966], vol. 2, p. 907). Second, the lexicalization of the root qt

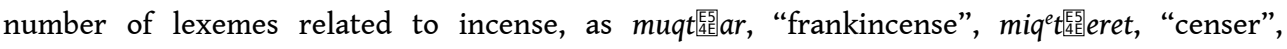

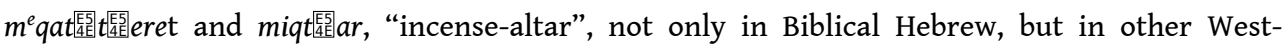
Semitic languages as Ugaritic and Punic ( $q t^{\left[E_{E}\right.} r t$, DNWSI 2, p. 1007), and in Jewish Aramaic

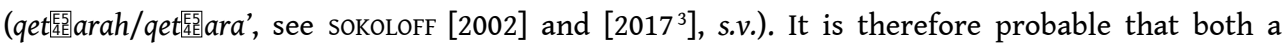
general and a more specific meaning are attested in the Hebrew Bible in different contexts. For an analysis of the distribution of the verb in the Hebrew Bible and in ancient Aramaic translations see HEGER (1997), p. 24-47.

31. See ZIEGLER (1939), p. 360, apparatus.

32. Pace SEELIGMAN (1948). The expression is also marked with an obelus by Jerome, a sign which indicates its presence in the old Greek text. The fluidity of this verse in antiquity is confirmed by a different and obscure reading preserved in one Qumran manuscript (1QIsa ${ }^{a}$, see ULRICH and FLINT, DJD 32, vol. 2, p. 190).

33. So also VAN DER VORM-CROUGH (2014), p. 468-469. For corrections which go in the same direction in the LXX of Isa 55-65 see BAER (2001), p. 176-177. On the wisdom discourse against idols in the Bible see recently AMMANN (2015). For somehow closer parallels to Isa 65:3 see Jeremiah

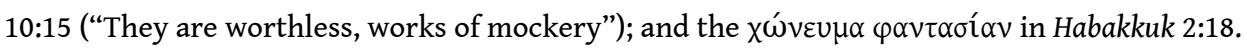

34. 1 En 99:7 according to the Chester Beatty papyrus (trad. Nickelsburg, Minneapolis, Fortress Press, 2001, slightly modified).

35. See e.g. Plutarch, The disappearance of oracles (Mor. 417b). 
36. Plutarch, Pelopidas, 21.5-6. Compare The disappearance of oracles (Mor. 417c-d). See GEORGIADOU (1997), p. 166-171. For a comment on the position of Plutarch himself towards these beliefs see BRENK (1977), p. 55 and (1998), p. 177.

37. Plutarch, Isis, 360a ff.; Strabo, 10.3.19.

38. On this topic, and on the way in which this discourse is taken over by ancient Christianity, see ANDERSON (2016); BARBU (2016), p. 40-88.

39. Deut 32:21.

40. Synesius of Cyrene, On dreams, 15.

41. Odyssey 11.471-476; 24.14; Herodotus, 5.92.

42. Iliad 5.449-453; Odyssey 4.796.

43. Aeschylus, Agamemnon, 839.

44. Plutarch, On the Pythian responses, 404c 10.

45. Lucian, Dialogues of the dead, 11.5 .

46. See the remarks of HAYWARD (2007), p. 44-45.

47. Qohelet 5:6.

48. See already HAWYARD (2007), p. 44-46.

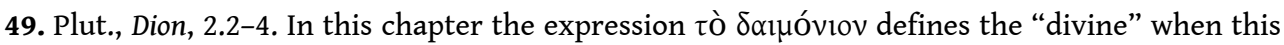
is manifested through a negative apparition. Interestingly enough, Plutarch seems here to have changed his mind in comparison to what he claims in the so-called pythian dialogues.

50. Ps 96: 5 (= 95:5 LXX).

51. See on this PREUSS (1974).

52. Ps 95: 4-5 (= 96: 4-5 MT)

53. See for example the Septuagint of Isaiah $2: 8 ; 2: 18,20 ; 10: 11 ; 19: 1 ; 31: 7$.

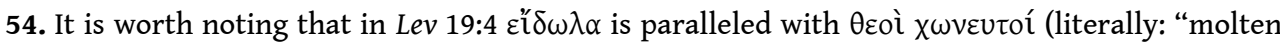
gods"). This expression insists on the artificial character and on the lifeless, inert materiality of

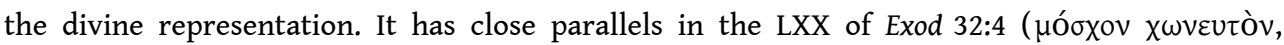

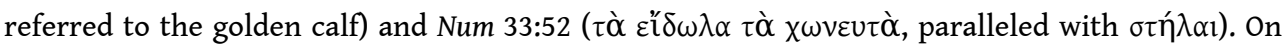
this aspect of $\varepsilon$ ǐ $\delta \omega \lambda$ ov, see further below, part 3.

55. 1Corinthians 10:19-21; Revelation 9:20.

56. For an analysis of this discourse see BARBU (2016).

57. VERNANT (1975), (1983) and (1990), in response to SAÏD (1987).

58. On this category, see the fundamental essay of VERNANT (1965); see also FRONTISI-DUCROUX (1980) and (1995); BETTINI (1991) and (1992). To the best of my knowledge, a comparative study of possible equivalent notions to express "identity" in Israelite and ancient Jewish culture is missing. It is my aim to explore more systematically this issue in a further study.

59. See on this episode BETTINI (1992), p. 12-16.

60. See on this LEVTOW (2008), p. 16-18; AMMANN (2015), p. 12-13.

61. See WEVERS (1977).

62. Gen 31:19, 34, 35.

63. BÜTSCHEL (1964); BARNES TATUM (1986).

64. BARNES TATUM (1986), p. 178-179.

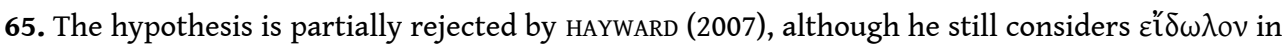
Exod 20:4 as meaning "idol".

66. Plato, Sophist, 240a-b; Republic $7.516 \mathrm{ff}$.

67. GRIFFITH (2002).

68. PStrasb. 2.91 (ed. Preisigke 1920).

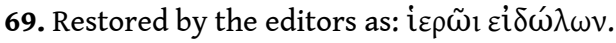

70. P.Worp 7 (= O. Garstand 1), ed. Boyaval 1980; Gallazzi 1985; Gascou 2008. On the oracular petitions as a genre see VERSNEL (1991). 
71. PSI 8901 (= Sel. Pap. 2.329).

72. Transl. Hunt and Edgar, Sel. Pap. 2.329, Loeb 1934.

73. IG XI 4, 1299, 88-90. See also ENGELMANN (1964) and LONGO (1969), n. 63, p. 106-116. More recently BRICAULT (2005), vol. I, no. 202/0101, p. 195-198. The translation of FURLEY (2012) with "ghosts" does not account for the material and rigid aspect of $\varepsilon$ ह $\delta \omega \lambda$ ov on which this verse insists.

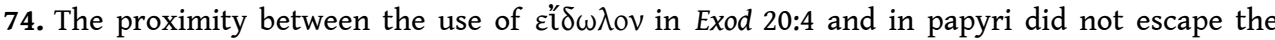
perceptive analysis of James Aitken, who observed that "the sense of $\varepsilon$ ' $\delta \omega \lambda$ ov as 'image' would seem to be the simplest reading of the passage" (AITKEN [2014], p. 193). See also LE BOULLUEC and SANDEVOIR (1989), p. 205-206.

75. In this regard, one can compare for example the different interpretation of the second commandment provided by Josephus (Jewish Antiquities 3.91) and Philo (Decalogue, 51).

\section{ABSTRACTS}

This paper discusses the representation of foreign gods as demons found in the Greek translation of the Hebrew Bible. It investigates the category of $\delta$ aı óviov in some Septuagint texts against the background of the Hellenistic literature, and the relationship between the notion of demon and that of idol. In doing this, it shows the relevance of the Septuagint for a better understanding of religious notions emerging during the Hellenistic period. Moreover, focusing on some uses of Ei $\delta \omega \lambda$ ov in the Pentateuch, the paper proposes a new interpretation for the word in the Greek version of the decalogue, in light of papyrological evidence.

Cette contribution analyse la représentation des dieux étrangers comme démons dans la

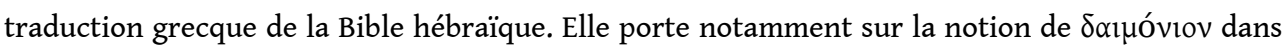
la Septante, approchée à partir d'autres témoignages hellénistiques, ainsi que sur la relation entre démons et idoles. Cette étude démontre également l'intérêt de la Septante pour une meilleure compréhension de l'émergence de nouvelles catégories religieuses à l'époque hellénistique. Enfin, en se focalisant sur des occurrences spécifiques d'ž́ $\delta \omega \lambda$ ov dans le Pentateuque et en les comparant avec la documentation papyrologique, elle propose une nouvelle interprétation du mot dans la version grecque du décalogue.

\section{AUTHOR}

\section{ANNA ANGELINI}

Université de Lausanne

Institut Romand des Sciences Bibliques

anna.angelini@unil.ch 